\title{
EVALUASI SISTEM PENGENDALIAN INTERNAL PIUTANG PADA DISTRIBUTOR UNILEVER INDONESIA AREA MANADO
}

\author{
Jones H. Yr Pondaag \\ David Paul Elia Saerang \\ Dhullo Affandi
}

\author{
Fakultas Ekonomi dan Bisnis, Jurusan Akuntansi \\ Universitas Sam Ratulangi Manado \\ email : pondaagjones@yahoo.com
}

\begin{abstract}
ABSTRAK
Sistem pengendalian piutang yang baik akan mempengaruhi keberhasilan perusahaan dalam menjalankan kebijakan penjualan secara kredit. Demikan pula sebaliknya, kelalaian dalam pengendalian piutang bisa berakibat fatal bagi perusahaan, misalnya banyak piutang yang tak tertagih karena lemahnya kebijakan pengumpulan dan penagihan piutang. Tujuan yang diharapkan dapat dicapai dalam penelitian ini adalah untuk menganalisis efektivitas sistem pengendalian internal piutang pada Distributor Unilever Indonesia Area Manado. Metode analisis yang digunakan adalah metode analisis deskriptif, dengan mengumpulkan, mengolah, dan menginterpretasikan data yang diperoleh sehingga memberi keterangan yang benar dan lengkap yang menggambarkan tentang bagaimana pengendalian internal piutang di Distributor Unilever Indonesia Area Manado. Hasil penelitian menunjukan bahwa Sistem Pengendalian Internal Piutang Di Distributor Unilever Indonesia Area Manado telah berjalan cukup baik. Distributor ini memiliki beberapa kebijakan dalam pemberian piutang. Akan tetapi mereka tidak memberikan jaminan apapun kepada pelanggan yang ingin memperoleh kredit. Dan di distributor ini pemberian piutang kepada pelanggan hanya berdasarkan kepercayaan dan berdasar atas masukan dari para sales. Kelemahan ini coba diantisipasi dengan giatnya para sales dalam menagih piutang kepada pelanggan mereka sebelum jatuh tempo.
\end{abstract}

Kata kunci : piutang, sistem pengendalian internal, piutang tak tertagih

\begin{abstract}
Good receivable control system willAffectthecompany's successincarryingout thesaleoncredit policy. Likewise, failure of receivable controlcan be fatalfor the company, for example,manydoubtfulreceivablesbecause weakpolicies of collection and accounts receivablecollection. Purpose which beachieved in this studywas toanalyzethe effectiveness ofthe internal controlsystemof receivable at Indonesian Distributor of Unilever in Manado Area. The analytical method usedis descriptive analysis method, tocollect, process, andinterpretthe data obtainedso as to givea true andcompletestatementdescribinghowinternal controlof receivable at Indonesian Distributor of Unilever in Manado Area. The results showedthat theInternalControlSystemof ReceivableatIndonesian Distributor of Unilever in Manado Areahas beengoing good enough. Thisdistributorhasseveralpoliciesin the provision ofreceivables. Buttheydo notgiveanyguaranteeto customerswhowant to havecredit. Andintheprovision ofdistributoraccountsto customersbased on trustandonlybasedon inputsfromthesales. This shortcomingtryanticipatedbyloyalsales forceincollecting accounts receivableto their customersbefore maturity.
\end{abstract}

Keywords : receivable, internal control system, doubtful receivable 


\section{PENDAHULUAN}

\section{Latar Belakang}

Ketika melaksanakan kegiatannya, setiap perusahaan yang berorientasi pada laba berusaha agar semua sumber daya yang ada dalam perusahaan digunakan seefisien mungkin agar perusahaan tersebut dapat terus bertahan dan berkembang. Untuk mencapai tujuan tersebut, maka pimpinan perusahaan harus selalu mengusahakan agar perusahaan berjalan sesuai dengan pola kebijaksanaan yang telah ditetapkan. Agar dapat menjalankan tugasnya dengan baik, pimpinan perusahaan memerlukan informasi yang terus-menerus sehingga keputusan-keputusan yang dihasilkan harus didasarkan atas data-data yang tepat, akurat, dan berkualitas. Guna mengatasi masalah-masalah yang semakin rumit dan kompleks, maka diperlukan suatu pengendalian intern guna pengawasan terhadap semua aktivitas yang ada dalam perusahaan. Suatu sistem informasi dapat dikatakan baik apabila di dalamnya telah menggambarkan sistem pengendalian intern yang diterapkan untuk menjaga kekayaan dan catatan perusahaan, mengecek ketelitan dan keandalan data akuntansi, mendorong efisiensi, serta mematuhi kebijakan manajemen. Secara umum piutang timbul karena adanya transaksi penjualan barang atau jasa secara kredit. Ditengah persaingan bisnis yang ketat perusahaan dituntut untuk mampu meraih posisi pasar, sehingga perusahaan perlu melakukan strategi penjualan secara kredit, agar jumlah penjualan meningkat. Namun, konsekuensi dari kebijakan tersebut dapat menimbulkan peningkatan jumlah piutang, piutang tak tertagih dan biaya-biaya lainnya yang muncul seiring dengan peningkatan jumlah piutang. Piutang merupakan salah satu jenis aktiva lancar yang tercantum dalam neraca. Untuk itu pengelolaan piutang memerlukan perencanaan yang matang, mulai dari penjualan kredit yang menimbulkan piutang sampai menjadi kas. Investasi yang terlalu besar dalam piutang bisa menimbulkan kecil atau lambatnya perputaran modal kerja, sehingga semakin kecil pula kemampuan perusahaan dalam meningkatkan volume penjualan. Akibatnya semakin kecilnya kesempatan yang dimiliki perusahaan untuk menghasilkan keuntungan atau laba. Peningkatan piutang yang diiringi oleh meningkatnya piutang tak tertagih perlu mendapat perhatian. Untuk itu sebelum suatu perusahaan memutuskan melakukan penjualan kredit, maka terlebih dahulu diperhitungkan mengenai jumlah dana yang diinvestasikan dalam piutang, syarat penjualan dan pembayaran yang diinginkan, kemungkinan kerugian piutang (piutang tak tertagih) dan biayabiaya yang akan timbul dalam menangani piutang. Oleh karena itu, pengendalian terhadap piutang merupakan sesuatu yang mutlak dilakukan oleh perusahaan. Sistem pengendalian piutang yang baik akan mempengaruhi keberhasilan perusahaan dalam menjalankan kebijakan penjualan secara kredit. Demikan pula sebaliknya, kelalaian dalam pengendalian piutang bisa berakibat fatal bagi perusahaan, misalnya banyak piutang yang tak tertagih karena lemahnya kebijakan pengumpulan dan penagihan piutang. Unilever merupakan sebuah perusahaan multinasional yang memproduksi barang konsumen yang bermarkas di Rotterdam, Belanda. Unilever memiliki beberapa cabang di berbagai negara. Di Indonesia sendiri, unilever didirikan pada 5 desember 1933 dengan nama Zeepfabrieken N.V. Lever. Pada 22 juli 1980, nama perusahaan diubah menjadi PT. Lever Brothers Indonesia, dan pada 30 juni 1997, nama perusahaan diubah menjadi PT. Unilever Indonesia Tbk. Di Indonesia, Unilever bergerak dalam bidang produksi sabun, deterjen, margarin, minyak sayur, dan makanan yang terbuat dari susu, es krim, makanan dan minuman dari teh, produk-produk kosmetik, dan produk rumah tangga. Untuk Distributor Unilever, piutang memegang peranan penting dalam penjualan produk-produk yang mereka jual. Nilai piutang yang terjadi di Distributor ini cukup besar. Meskipun hanya sekitar $10 \%$ dari total pelanggan yang membeli secara kredit di Distributor ini, nilai penjualan yang berasal dari piutang lebih besar daripada penjualan secara tunai. Oleh karena itu piutang ini memiliki peranan yang sangat penting atas penjualan di Distributor ini. Untuk menjaga agar piutang ini aman, maka perusahaan haruslah memiliki pengendalian internal piutang yang baik.

\section{Tujuan Penelitian}

Tujuan penelitian adalah untuk mengetahui efektivitas sistem pengendalian internal piutang pada Distributor Unilever Indonesia Area Manado. 


\section{TINJAUAN PUSTAKA}

\section{Akuntansi Keuangan}

Akuntansi keuangan berorientasi pada pelaporan pihak eksternal. Beragamnya pihak eksternal dengan tujuan spesifik bagi masing-masing pihak membuat pihak penyusun pelaporan keuangan menggunakan prinsip dan asumsi-asumsi dalam proses penyusunan laporan keuangan. Laporan keuangan yang dihasilkan dari akuntansi keuangan berupa laporan keuangan untuk tujuan umum (general purpose financial statement). Laporan keuangan bertujuan umum adalah laporan keuangan yang ditujukan untuk memenuhi kebutuhan bersama sebagian besar laporan pengguna laporan. Laporan keuangan untuk tujuan umum disusun berdasarkan data dan informasi yang telah terjadi sehingga lebih berorientasi pada data historis (Martani, dkk. 2012: 8).

Laporan keuangan yang disajikan kepada pemakai eksternal biasanya memang jauh lebih ringkas daripada informasi yang dilaporkan untuk kepentingan internal. Dapat dipahami, perusahaan tidak ingin menungkap secara terperinci masalah keuangan internal perusahaan kepada pihak luar. Laporan internal cenderung memiliki lebih banyak kategori pendapatan dan beban, yang biasanya dikelompokkan sepanjang lini pertanggungjawaban. Rincian ini memungkinkan manajemen puncak untuk menilai kinerja para stafnya (Hery, 2009: 2).

\section{Sistem Informasi Akuntansi}

Sebuah sistem akuntansi dirancang untuk menunjukkan kenaikan ataupun penurunan saldo masing-masing komponen laporan keuangan. Kenaikan ataupun penurunan saldo ini haruslah dicatat secara terperinci dan terpisah untuk setiap komponen laporan keuangan. Catatan akuntansi yang terperinci dan terpisah inilah yang dinamakan sebagai akun (perkiraan). Jadi, akun adalah catatan akuntansi mengenai kenaikan atau penurunan saldo dari masingmasing aktiva, kewajiban, dan ekuitas. Daftar yang memuat mengenai keseluruhan kode (nomor) dan nama akun disebut bagan perkiraan (chart of accounts). Kode dan nama akun yang terdapat di dalam daftar merupakan kode dan nama akun yang akan digunakan oleh perusahaan untuk mencatat dan mengklasifikasikan setiap transaksi bisnis (peristiwa ekonomi) yang terjadi (Hery, 2009:58-59).

\section{Piutang}

Piutang dagang (Accounts Receivable atau Trade Receivable) merupakan tagihan yang timbul atau diperoleh karena adanya kegiatan penjualan barang atau jasa secara kredit (tidak tunai).Piutang dagang timbul dari penjualan kredit barang atau Jasa yang merupakan usaha pokok perusahaan. Bila piutang timbul dari penjualan asset perusahaan, pemberian pinjaman kepada pihak tertentu maka piutang tersebut tidak termasuk golongan piutang dagang.Adalah suatu kebiasaan bagi perusahaan untuk memberikan kelonggaran kepada para pelanggan pada waktu melakukan penjualan. Kelonggaran-kelonggaran yang diberikan biasanya dalam bentuk memperbolehkan para pelanggan tersebut membayar kemudian atas penjualan barang atau jasa yang dilakukan. Penjualan dengan syarat demikian disebut penjualan kredit.Sisi lain dari penjualan kredit adalah timbulnya piutang. Piutang merupakan klaim (hak untuk mendapatkan) uang dari entitas lain. Ini berarti perusahaan mempunyai hak klaim terhadap seseorang atau perusahaan lain. Dengan adanya hak klaim ini perusahaan dapat menuntut pembayaran dalam bentuk uang atau penyerahan aktiva atau jasa lain kepada pihak dengan siapa ia berpiutang. Oleh karena adanya manfaat (dalam bentuk diterimanya uang tunai, aktiva lain, atau jasa) yang diharapkan dapat diperoleh di masa datang, maka piutang dianggap sebagai aktiva.Piutang pada umumnya dapat dikelompokkan menjadi piutang dagang dan piutang lain-lain. Piutang yang berasal dari penjualan barang dan jasa yang merupakan kegiatan usaha normal perusahaan disebut piutang dagang atau piutang usaha (trade receivable). Disamping piutang dagang, terdapat piutang-piutang jenis lain misalnya piutang pegawai, piutang bunga, piutang dari perusahaan afiliasi, piutang pemegang saham, dan lain-lain (Sumarsan,2011: 338).

Piutang pada umumnya dapat dikelompokkan menjadi piutang dagang dan piutang lain-lain. Piutang yang berasal dari penjualan barang dan jasa yang merupakan kegiatan usaha normal perusahaan disebut piutang dagang atau piutang usaha (trade receivable). Disamping piutang dagang, terdapat piutang-piutang jenis lain misalnya 
piutang pegawai, piutang bunga, piutang dari perusahaan afiliasi, piutang pemegang saham, dan lain-lain (Soemarso,2009: 338).

Ada tiga cara pengelompokkan piutang. Pertama, piutang dapat dikelompokkan menjadi piutang dagang dan piutang wesel. Piutang dagang tercipta sebagai akibat dari penjualan kredit tanpa dukungan dokumen formal. Piutang wesel merupakan janji tertulis (dalam sebuah dokumen formal) untuk membayar sejumlah uang, disebut pokok, pada satu tanggal tertentu di masa yang akan datang, dikenal dengan istilah tanggal jatuh tempo, dan sejumlah bunga pada tanggal tertentu di masa yang akan datang. Bunga merupakan jumlah yang dibebankan atas penggunaan pokok pinjaman.Kedua, piutang dapat dikelompokkan sebagai piutang dagang dan piutang non dagang. Piutang dagang merupakan piutang yang timbul dalam operasi normal suatu kegiatan bisnis pada saat terjadi penjualan barang dagangan secara kredit. Piutang non dagang muncul dari transaksi selain penjualan barang atau jasa. Sebagai contoh, jika seorang manajer keuangan memberi pinjaman uang kepada orang lain dalam perusahaan tersebut, maka pinjaman tersebut akan dikelompokkan sebagai piutang non dagang.Ketiga, dalam neraca, piutang juga dapat diklasifikasikan sebagai piutang lancar dan piutang tidak lancar (piutang jangka pendek dan piutang jangka panjang), tergantung pada kapan kas diharapkan dapat tertagih (Libby, et al.2008: 288).

Beberapa masalah dasar dalam akuntansi untuk piutang usaha yaitu:

\section{Pengakuan piutang usaha}

Dalam sebagian besar transaksi piutang, jumlah yang harus diakui adalah harga pertukaran diantara kedua belah pihak. Harga pertukaran adalah jumlah yang terhutang dari debitur (seorang pelanggan atau peminjam) dan umumnya dibuktikan dengan beberapa jenis dokumen bisnis, biasanya berupa faktur.

\section{Penilaian piutang usaha}

Pelaporan piutang melibatkan klasifikasi dan penilaian dalam neraca. Klasifikasi, melibatkan penentuan lamanya waktu setiap piutang akan beredar. Piutang yang diperkirakan akan tertagih dalam satu tahun atau satu siklus operasi - tergantung mana yang lebih panjang - diklasifikasikan sebagai lancar; sementara semua piutang lainnya diklasifikasikan sebagai jangka panjang. Penilaian piutang sedikit lebih kompleks. Piutang jangka pendek dinilai dan dilaporkan pada nilai realisasi bersih (jumlah bersih yang diperkirakan akan diterima dalam bentuk kas), yang tidak selalu berupa jumlah yang secara resmi merupakan piutang. Penentuan nilai realisasi bersih memerlukan estimasi baik atas piutang yang tak tertagih maupun retur penjualan dan pengurangan harga yang diberikan.

\section{Disposisi piutang usaha}

Dalam peristiwa yang normal, piutang usaha dan wesel tagih dapat ditagih pada saat jatuh tempo dan dikeluarkan dari pembukuan. Namun, seiring dengan meningkatnya ukuran dan signifikansi dari penjualan kredit dan piutang "peristiwa yang normal ini" telah berubah. Dalam rangka mempercepat penerimaan kas dari piutang, pemilik dapat mentransfer piutang usaha kepada perusahaan lainnya secara tunai (Kieso, et al. $2008: 348$ ).

\section{Pengendalian Internal}

Setiap perusahaan pasti menghendaki adanya keamanan pada harta kekayaannya, menginginkan laba yang memadai dan akhirnya kelangsungan dan perkembangan usaha. Untuk mencapai hal tersebut, perusahaan harus meyakinkan bahwa kondisi internal perusahaan mampu memberikan jaminan bahwa kekayaan pemilik perusahaan terjaga dari kemungkinan kecurangan yang merugikan pemilik perusahaan. Selain itu, pemilik juga menginginkan adanya informasi keuangan dari manajemen yang dapat dipercaya.Agar tujuan-tujuan tersebut dapat dicapai, maka perlu adanya suatu sistem pengendalian internal yang memadai. Pengendalian internal mempunyai pengertian penyusunan organisasi, serta penerapan metode-metode untuk menjaga harta milik perusahaan, meyakinkan bahwa catatan-catatan akuntansi dapat dipercaya, efisiensi operasi bisa dijaga, dan kebijakan manajemen ditaati oleh karyawan. 
Pada dasarnya pengendalian intern dibagi menjadi dua, yaitu pengendalian internal akuntansi dan pengendalian internal administrasi. Pengendalian internal administrasi mempunyai tujuan meningkatkan efisiensi operasi dan meyakinkan bahwa kebijakan manajemen ditaati karyawan. Sedangkan pengendalian internal akuntansi mempunyai tujuan agar harta milik perusahaan bisa terjaga dari kecurangan dan agar catatan-catatan akuntasi dapat dipercaya (Tjahjono, 2009: 2). efektif:

Biasanya manajemen memiliki tiga tujuan umum dalam merancang sistem pengendalian internal yang

1. Reliabilitas pelaporan keuangan

Manajemen bertanggung jawab untuk menyiapkan laporan bagi para investor, kreditor, dan pemakai lainnya. Manajemen memikul baik tanggung jawab hukum maupun profesional untuk memastikan bahwa informasi telah disajikan secara wajar sesuai dengan persyaratan pelaporan seperti prinsip prinsip akuntansi yang berlaku umum. Tujuan pengendalian internal yang efektif atas pelaporan keuangan adalah memenuhi tanggung jawab pelaporan keuangan tersebut.

\section{Efisiensi dan efektifitas operasi}

Pengendalian dalam perusahaan akan mendorong pemakaian sumber daya secara efisien dan efektif untuk mengoptimalkan sasaran sasaran perusahaan. Tujuan yang penting dari pengendalian ini adalah memperoleh informasi keuangan dan nonkeuangan yang akurat tentang operasi perusahaan untuk keperluan pengambilan keputusan.

\section{Ketaatan pada hukum dan peraturan}

Section 404 (SOX) mengharuskan semua perusahaan publik mengeluarkan laporan tentang keefektifan pelaksanaan pengendalian internal atas pelaporan keuangan. Selain mematuhi ketentuan hukum dalam Section 404 (SOX), organisasi organisasi publik, nonpublik, dan nirlaba diwajibkan menaati berbagai hukum dan peraturan (Arens, et al. 2008: 370).

Sistem pengendalian internal perusahaan pada umumnya dirancang untuk memberikan jaminan yang memadai bahwa aktiva perusahaan telah diamankan secara tepat dan bahwa catatan akuntansi dapat diandalkan.Faktor manusia adalah faktor yang sangat penting dalam setiap pelaksanaan sistem pengendalian internal. Sebuah sistem pengendalian yang baik dapat menjadi tidak efektif karena adanya karyawan yang kelelahan, ceroboh, atau bersikap acuh tak acuh. Demikian juga halnya dengan kolusi, dimana kolusi ini secara signifikan dapat mengurangi keefektifan sebuah sistem dan mengeliminasi proteksi yang ditawarkan dari pemisahan tugas (Hery, 2008:165).

\section{Pengendalian Internal Piutang}

Dalam fungsi akuntansi, fungsi yang berhubungan harus dipisahkan. Dengan demikian maka pekerjaan seorang karyawan dapat berfungsi sebagai alat kontrol bagi pekerjaan karyawan lainnya. Contoh, tanggung jawab untuk melakukan pembukuan buku pembantu piutang harus dipisahkan dari pembukuan buku besar piutang. Pekerjaan petugas pembukuan buku pembantu piutang dapat dicek dengan menjumlahkan total saldo rekening masing-masing individu (pelanggan) dalam buku pembantu piutang dan membandingkan dengan rekening buku besar piutang yang dikerjakan oleh petugas pembukuan buku besar piutang.

Pengendalian pada piutang dagang dimulai dari pengesahan penjualan kredit oleh manajer perusahaan yang diberi otorisasi. Prosedur pemberian persetujuan penjualan kredit dilakukan oleh departemen kredit perusahaan. Selain itu prosedur untuk mengotorisasi penyesuaian piutang seperti retur penjualan dan potongan penjualan harus diatur. Prosedur penagihan piutang juga harus dibuat untuk memastikan piutang ditagih tepat waktu dan untuk meminimalkan kemungkinan kerugian dari piutang yang tidak dapat ditagih.Kalau kita berbicara 
mengenai pengendalian internal atas piutang usaha, maka sesungguhnya yang menjadi pusat perhatian adalah bagaimana pengemanan yang efisien dan efektif dilakukan atas piutang usaha, baik dari segi pengamanan atas perolehan fisik kas, pemisahan tugas (termasuk masalah otorisasi persetujuan kredit), sampai pada tersedianya data catatan akuntansi yang akurat.

Setiap pengajuan kredit yang dilakukan oleh calon pembeli haruslah diuji atau dievaluasi terlebih dahulu kelayakan kreditnya. Bagian penjualan tidak boleh merangkap bagian kredit. Persetujuan pemberian kredit hanya boleh dilakukan oleh manajer kredit. Manajer penjualan tidaklah memiliki otorisasi atau wewenang untuk menyetujui proposal kredit pelanggan. Apabila bagian penjualan merangkap bagian kredit, maka dikhawatirkan seluruh proposal kredit yang diajukan calon pembeli akan langsung disetujui tanpa adanya evaluasi terlebih dahulu. Dalam hal ini, kemungkinan besar risiko akan muncul terutama terhadap calon pembeli dengan peringkat kredit yang buruk. Dalam praktik, ketiadaan pemisah tugas antara fungsi penjualan dengan fungsi kredit, ditambah lagi dengan kurang tepatnya dasar penghitungan komisi, seringkali menimbulkan peluang terjadinya tindakan kecurangan. Tidak mustahil, karyawan bagian penjualan akan berusaha memperbesar komisi penjualan dengan cara yang tidak benar; dimana oknum bagian penjualan akan membuat seolah-olah penjualan barang dagangan ke pelanggan sungguhan terjadi, padahal penjualan tersebut dilakukan secara fiktif (barang tidak dijual ke pelanggan sungguhan namun disembunyika). Nanti, begitu komisi diperoleh, oknum karyawan tadi akan mengembalikan barang yang telah disembunyikan, seolah-olah telah terjadi retur dari pembeli.

Seperti kita ketahui, penerapan pengendalian internal memang tidak terlepas dari biaya-biaya tambahan yang harus dikorbankan perusahaan. Dalam hal ini, ingat kembali bahwa perusahaan pada dasarnya harus mempertimbangkan atau membandingkan antara besarnya biaya tambahan yang akan dikeluarkan (dalam rangka efektifnya pemisahan tugas) dengan manfaat yang akan diperoleh. Atas dasar pertimbangan cost dan benefit tadi, apabila perusahaan pada akhirnya lebih memilih untuk merangkap kedua fungsi (antara fungsi penjualan kredit dengan fungsi penjualan), maka dasar penghitungan komisi haruslah berdasarkan pada tingkat kolektibilitas piutang, bukan omset penjualan. Artinya, komisi penjualan akan dihitung berdasarkan pada besarnya piutang usaha (yang ditimbulkan dari penjualan kredit) yang telah berhasil ditagih atau dikonversi menjadi uang kas.

Akan tetapi, secara normatif, jika kita berbicara mengenai pemisahan tugas (dalam kaitannya dengan pengendalian internal atas piutang usaha) maka harus adanya pemisahan fungsi antara bagian persetujuan kredit, bagian penjualan, bagian pencatatan (akuntansi), dan bagian penagihan. Fungsi persetujuan kredit dan fungsi pembukuan memegang peranan sebagai pengecek keabsahan penjualan. Karyawan yang menangani pencatatan piutang usaha tidak boleh ikut terlibat dalam aktivitas penagihan (Hery, 2009: 269-270). 


\section{Penelitian Terdahulu}

\section{Tabel 1 Penelitian Terdahulu}

\begin{tabular}{|c|c|c|c|c|c|c|}
\hline Nama/tahun & Judul & Tujuan & Analisis & Hasil & Persamaan & Perbedaan \\
\hline $\begin{array}{l}\text { Setiawan/ } \\
2008\end{array}$ & $\begin{array}{l}\text { Analisis } \\
\text { Pengaruh } \\
\text { Manajemen } \\
\text { Piutang Dan } \\
\text { Persediaan } \\
\text { Terhadap } \\
\text { Profitabilitas } \\
\text { Perusahaan } \\
\text { Manufaktur } \\
\text { Yang Listing Di } \\
\text { Jakarta Islamic } \\
\text { Index Tahun } \\
\text { 2001-2006 }\end{array}$ & $\begin{array}{l}\text { Untuk } \\
\text { mengetahui } \\
\text { pengaruh } \\
\text { manajemen } \\
\text { piutang dan } \\
\text { persediaan } \\
\text { terhadap } \\
\text { peningkatan } \\
\text { profitabilitas } \\
\text { perusahaan }\end{array}$ & $\begin{array}{l}\text { Regresi } \\
\text { Linier } \\
\text { Berganda }\end{array}$ & $\begin{array}{l}\text { Variabel yagn } \\
\text { digunakan sebagai } \\
\text { pengukur manajemen } \\
\text { piutang adalah } \\
\text { perputaran piutang } \\
\text { sedangkan variabel } \\
\text { yang digunakan } \\
\text { sebagai pengukur } \\
\text { manajemen } \\
\text { persediaan adalah } \\
\text { perputaran } \\
\text { persediaan.Sedangkan } \\
\text { profitabilitas diwakili } \\
\text { oleh rasio } \\
\text { profitabilitas yaitu } \\
\text { return on } \\
\text { investment.Populasi } \\
\text { dalam penelitian ini } \\
\text { adalah } 12 \text { perusahaan } \\
\text { manufaktur yang } \\
\text { listing di Jakarta } \\
\text { Islamic Index selama } \\
\text { 2001-2006 }\end{array}$ & $\begin{array}{l}\text { Setiawan } \\
\text { mengambil data } \\
\text { dari perusahaan } \\
\text { manufaktur yang } \\
\text { listing di Jakarta } \\
\text { Islamic Index. } \\
\text { Sedangkan } \\
\text { penelitian ini } \\
\text { mengambil data } \\
\text { di Distributor } \\
\text { Unilever Manado }\end{array}$ & $\begin{array}{l}\text { Kedua penelitian } \\
\text { ini menggunakan } \\
\text { piutang sebagai } \\
\text { subjek penelitian }\end{array}$ \\
\hline $\begin{array}{l}\text { Wicaksana/ } \\
2010\end{array}$ & $\begin{array}{l}\text { Analisis } \\
\text { Pengaruh } \\
\text { Pengendalian } \\
\text { Piutang Terhadap } \\
\text { Efektivitas Arus } \\
\text { Kas (Studi Kasus } \\
\text { pada PT. Z) }\end{array}$ & $\begin{array}{l}\text { Untuk } \\
\text { mengetahui } \\
\text { pengaruh } \\
\text { pengendalian } \\
\text { piutang } \\
\text { terhadap } \\
\text { efektivitas } \\
\text { arus kas } \\
\text { perusahaan }\end{array}$ & $\begin{array}{l}\text { Analisis Per } \\
\text { Komponen, } \\
\text { Analisis } \\
\text { Trend, } \\
\text { Analisis } \\
\text { Cash } \\
\text { Conversion } \\
\text { Cycle, Dan } \\
\text { Analisis } \\
\text { Rasio } \\
\text { Keuangan }\end{array}$ & $\begin{array}{l}\text { Hasil dari penelitian } \\
\text { ini menunjukkan } \\
\text { bahwa berdasarkan } \\
\text { analisis terhadap } \\
\text { sistem manajemen } \\
\text { piutang yang } \\
\text { dilakukan, PT. Z telah } \\
\text { melakukan proses } \\
\text { manajemen, } \\
\text { pengelolaan, dan } \\
\text { pengendalian piutang } \\
\text { berdasarkan SOP } \\
\text { (Standard Operation } \\
\text { Procedure) yang telah } \\
\text { ditetapkan oleh } \\
\text { perusahaan, namun } \\
\text { dalam } \\
\text { pelaksanaannya } \\
\text { masih terdapat } \\
\text { beberapa hal yang } \\
\text { tidak sesuai dengan } \\
\text { SOP. }\end{array}$ & $\begin{array}{l}\text { Wicaksana } \\
\text { menggunakan } \\
\text { analisis per } \\
\text { komponen, } \\
\text { analisis trend, } \\
\text { analisis cash } \\
\text { conversion cycle, } \\
\text { dan analisis rasio } \\
\text { keuangan. } \\
\text { Sedangkan } \\
\text { penelitian ini } \\
\text { menggunakan } \\
\text { analisis deskriptif }\end{array}$ & $\begin{array}{l}\text { Kedua penelitian } \\
\text { ini menggunakan } \\
\text { data primer dan } \\
\text { data sekunder. }\end{array}$ \\
\hline
\end{tabular}

\section{METODE PENELITIAN}

\section{Jenis Penelitian}

Jenis penelitian yang digunakan penulis dalam penyusunan skripsi Evaluasi Sistem Pengendalian Internal Piutang pada Distributor Unilever Indonesia Area Manado ini adalah jenis penelitian deskriptif, yaitu suatu penelitian dengan mengumpulkan data-data yang menggambarkan seluruh kegiatan berdasarkan fakta yang ada lalu 
mengolah dan menganalisa data kemudian menarik kesimpulan serta menginter-pretasikannya.Dalam pembahasan ini diperlukan data yang dapat mendukung pemecahan masalah yang ada. Jenis data yang digunakan adalah data kualitatif yaitu berupa sejarah perusahaan, struktur organisasi perusahaan dan kebijakan akuntansi yang diberlakukan dalam perusahaan serta informasi yang dibutuhkan untuk mendukung penelitian ini (Sugiyono, 2011: 8)

\section{Tempat dan Waktu Penelitian}

Penelitian dilakukan di Distributor Unilever Indonesia Area Manado, yang berlokasi di Kairagi. Waktu penelitian yaitu pada Bulan Februari-Maret tahun 2013.

\section{Prosedur Penelitian}

Penelitian diawali dengan mewawancarai Manajemen Operasional yang bertanggung jawab atas jalannya operasional perusahaan. Manajemen Operasional kemudian memberikan data-data yang diperlukan.

\section{Teknik Pengumpulan Data}

Adapun teknik pengumpulan data yang digunakan dalam penelitian ini adalah sebagai berikut:

1. Penelitian lapangan, merupakan penelitian langsung yang dilakukan pada perusahaan bersangkutan, dimana data-data yang diambil sebagian besar diperoleh dari hasil wawancara dengan manajemen perusahaan dan melalui daftar pertanyaan (kusioner).

2. Penelitian dokumentasi, penelitian ini menggunakan data-data yang diperoleh dari dokumentasi perusahaan yang berhubungan dengan penelitian ini.

\section{Metode Analisis}

Metode analisis yang digunakan yaitu metode analisis deskriptif yang mengevaluasi karakteristik transaksi piutang dagang dan pencatatnnya pada Distributor Unilever Indonesia Area Manado.Adapun teknik analisis yang dilakukan dalam penelitian ini adalah analisis deskriptif dengan langkah-langkah sebagai berikut:

1. Mempelajari prosedur-prosedur yang ada dalam penjualan produk-produk perusahaan.

2. Mempelajari sistem dan prosedur pencatatan piutang di perusahaan.

3. Melakukan evaluasi terhadap piutang di perusahaan.

4. Menarik kesimpulan serta saran mengenai hasil evaluasi terhadap transaksi piutang dagang.

\section{HASIL PENELITIAN DAN PEMBAHASAN}

\section{Sistem dan Prosedur Penjualan Kredit}

Pemberian kredit untuk konsumen ditangani oleh para sales. Akan tetapi, para sales harus meminta persetujuan dari supervisor sales bilamana konsumen tersebut layak diberikan kredit atau tidak. Supervisor sales kemudian menganalisis konsumen mana yang layak diberikan kredit dan mana yang tidak layak. 


\section{Gambar 1 Flowchart sistem dan prosedur penjualan kredit}

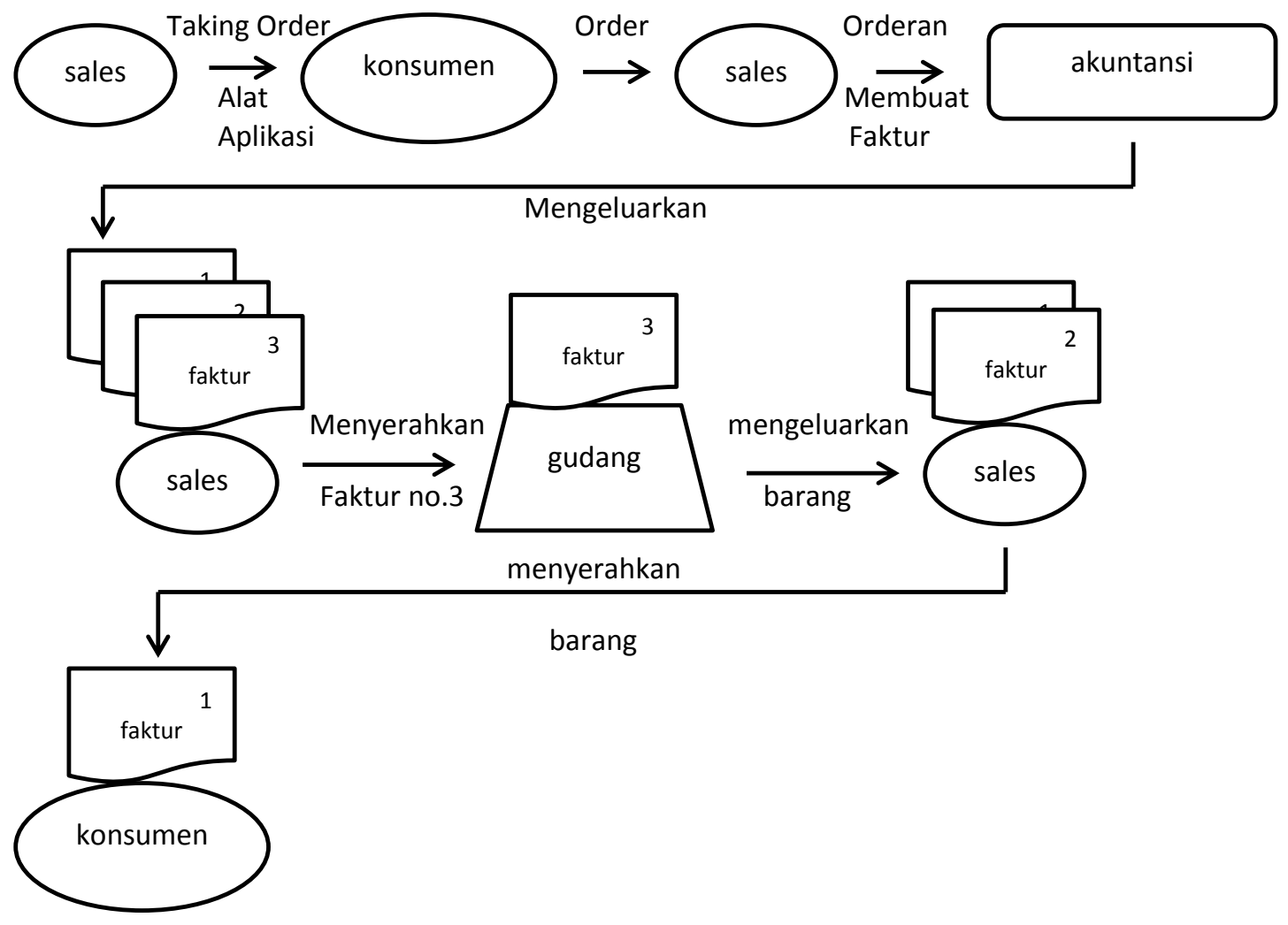

\section{Sumber: Distributor Unilever Manado (olahan 2013)}

Prosedur penjualan kredit di distributor ini dimulai ketika sales melakukan Taking Order (TO) kepada para konsumen. Sales bertanya kepada pihak toko atau outlet produk-produk apa yang akan dipesan untuk dibeli. Setiap sales selalu membawa sebuah alat aplikasi yang terhubung dengan bagian gudang. Apabila konsumen ingin memesan suatu barang, sales akan mengecek barang tersebut lewat alat yang mereka bawa. Mereka dapat mengetahui lewat alat tersebut bilamana persediaan barang yang dipesan masih tersedia di gudang atau sudah habis.Setelah konsumen selesai memesan barang, sales akan kembali ke distributor untuk membuat faktur berdasarkan jumlah barang yang telah dipesan oleh konsumen yang telah dimasukkan ke dalam alat tersebut. Bagian akuntansi mengeluarkan faktur 3 rangkap yang nantinya akan dibawa ke toko-toko yang telah memesan barang tersebut.

Faktur penjualan rangkap ketiga kemudian diberikan kepada bagian gudang untuk mengangkut barang yang telah dipesan dan dimasukkan ke dalam mobil pengangkut untuk dibawa kepada konsumen yang telah memesan barang tersebut sebelumnya. Setelah barang tiba pada konsumen, konsumen mengecek apakah barang-barang yang dibawa sesuai dengan faktur atau tidak. Jika telah sesuai, faktur rangkap pertama ditahan oleh konsumen, dan faktur rangkap kedua dipegang oleh sales untuk diberikan ke bagian kasir untuk mencatat terjadinya transaksi penjualan kedit.

Bagian akuntansi mencatat transaksi piutang dengan akun sebagai berikut:

\begin{tabular}{|c|c|c|}
\hline 4 April 2013 & Piutang & Rp xxx \\
\hline
\end{tabular}


Kemudian bagian akuntansi membuat rekap tagihan selama seminggu untuk ditagih pada saat jatuh tempo.Jika ada konsumen yang akan mengajukan kredit langsung ke pihak distributor, konsumen harus bertemu dengan sales terebih dahulu. Sales yang nantinya akan pergi ke bagian akuntansi dan bagian akuntansi akan mengeluarkan faktur berdasarkan jumlah barang yang telah dipesan oleh konsumen. Faktur rangkap ketiga diberikan ke bagian gudang untuk mengeluarkan barang-barang yang telah dipesan. Sales kemudian menyerahkan barang-barang tersebut kepada konsumen beserta faktur rangkap pertama sebagai bukti kredit dan faktur rangkap kedua dipegang oleh sales sebagai bukti pada waktu penagihan kredit.

\section{Sistem dan Prosedur Penagihan dan Penerimaan Kas}

Sistem dan prosedur penagihan piutang di distributor unilever adalah sebagai berikut:

\section{Gambar 2 Flowchart Sistem dan Prosedur Penagihan}

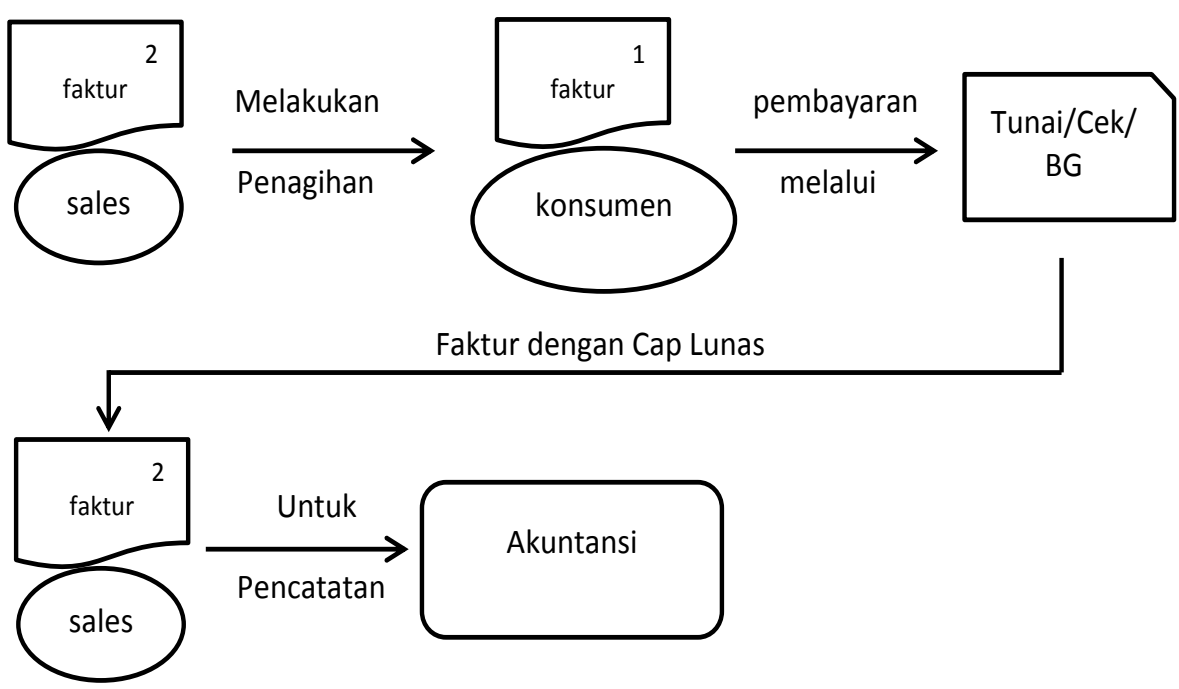

\section{Sumber: Distributor Unilever Manado (olahan 2013)}

Pada saat jatuh tempo pembayaran, para sales akan pergi ke konsumen untuk melakukan penagihan. Sales membawa faktur rangkap kedua yang dipegang sebagai bukti penagihan. Pembayaran yang dilakukan oleh konsumen seringkali lewat beberapa cara. Konsumen dapat membayar secara tunai atau dengan uang cash, mereka juga dapat membayar melalui Cek atau BG (Bilyet Giro). Pembayaran melalui BG harus mengikuti tanggal jatuh tempo atau umur piutang. Sehingga sales dapat mengambil atau memindahbukukan BG tersebut ke rekening Distributor pada saat jatuh tempo.

Setelah konsumen melunasi piutang mereka, sales membawa bukti pembayaran, berupa faktur yang telah di tandai atau di cap "Lunas" oleh sales itu sendiri. Setelah pelunasan, bagian akuntansi mencatat pelunasan piutang dengan akun sebagai berikut:
11 April $2013 \quad$ Kas
$\operatorname{Rp} x x x$

Piutang $\quad \operatorname{Rp} x x$

\section{Sistem dan Prosedur Penghapusan Piutang}

Pihak distributor sangat jarang dalam melakukan penghapusan piutang, karena sangat jarang terjadi kerugian akibat piutang tak tertagih di Distributor Unilever Area Manado ini. Akan tetapi distributor ini menggunakan metode penghapusan langsung apabila terjadi kerugian piutang. Mereka memiliki batas waktu yang cukup lama, yaitu 1 tahun untuk menentukan apakah piutang tersebut sudah tidak akan terbayar atau terjadi 
kerugian piutang. Setelah batas waktu yang ditentukan telah lewat, bagian akuntansi akan melakukan penghapusan terhadap piutang yang tak tertagih.

Contoh pencatatan penghapusan piutang adalah sebagai berikut:

Beban Piutang Tak Tertagih $\quad$ Rp xxx

Piutang Usaha $\quad$ Rp xxx

\section{PENUTUP}

\section{Kesimpulan}

1. Piutang di Distributor Unilever Area Manado sudah cukup memadai meskipun tidak memiliki jaminan atas piutang mereka. Karena berdasarkan penjelasan dari para ahli, piutang usaha tidak memiliki dukungan dari dokumen formal atau jaminan sehingga distributor hanya mengandalkan kepercayaan mereka terhadap pelanggan.

2. Sistem dan prosedur penjualan kredit di distributor unilever ini cukup memadai karena sistem penjualan kredit yang mereka terapkan berdasarkan sistem penjualan kredit seperti pada umumnya. Hanya saja mereka harus memiliki departemen kredit untuk tujuan memverifikasi kelayakan pemberian kredit kepada pelanggan.

3. Sistem penagihan disini belum cukup memadai, karena mereka tidak memiliki penagih yang berfungsi untuk menagih piutang mereka yang telah jatuh tempo. Mereka hanya mengandalkan sales mereka dalam hal penagihan piutang.

4. Sistem penerimaan kas distributor ini sudah cukup memadai meskipun tidak memiliki kuitansi sebagai bukti pelunasan atau telah diterimanya pembayaran dari pelanggan. Akan tetapi, distributor mengakalinya dengan meminta tanda tangan atau cap dari pelanggan sebagai bukti pembayaran atau pelunasan piutang.

5. Metode penghapusan langsung yang diterapkan oleh distributor tidak memadai untuk perusahaan dengan skala penjualan relatif besar seperti mereka. Karena menurut Standar Akuntansi Keuangan yang ada, perusahaan dengan skala penjualan yang besar seharusnya menggunakan metode pencadangan untuk mengestimasi piutang mereka yang berpotensi terjadi kerugian piutang.

\section{Saran}

1. Distributor sebaiknya menggunakan jaminan untuk melindungi piutang mereka dari kemungkinan terjadinya kerugian piutang.

2. Distributor sebaiknya membuat departemen kredit yang berfungsi sebagai pihak yang melakukan verifikasi atas kelayakan pemberian kredit bagi pelanggan.

3. Distributor harus memiliki fungsi penagihan sebagai pihak yang melakukan penagihan pada saat piutang telah jatuh tempo, sehingga dapat meringankan tugas dari para sales.

4. Distributor bisa mempertimbangkan untuk menggunakan kuitansi sebagai bukti yang kuat atas pelunasan pembayaran piutang dari pelanggan dan bukti untuk pencatatan penerimaan kas.

5. Pihak distributor harusnya menggunakan metode pencadangan piutang untuk mengestimasi piutang usahanya yang memiliki resiko terjadinya kerugian piutang.

\section{DAFTAR PUSTAKA}

Arens, Alvin A., Elder, Randal J., Beasley, MarkS. (Alih bahasa oleh Gina Gania). 2008.Auditing dan Jasa Assurance.Jilid 1. Edisi Keduabelas. Erlangga. Jakarta.

Hery. 2008.Pengantar Akuntansi 1. Fakultas Ekonomi Universitas Indonesia. Jakarta. 
2009.Akuntansi Keuangan Menengah I. Edisi 1. Cetakan Pertama. PT. Bumi Aksara. Jakarta.

Kieso, Donald E., Weygandt, Jerry J., Warfield, Terry D. (Alih bahasa oleh Emil Salim SE). 2008.Akuntansi Intermediate. Jilid 1. Edisi Keduabelas. Erlangga. Jakarta.

Libby, Robert., Libby, Patricia A.,Short, Daniel G. (alih bahasa oleh J. Agus Seputro). 2008.Akuntansi Keuangan. Andi. Yogyakarta.

Martani, Dwi., Veronica, Silvya NPS., Wardhani, R.,Farahmita, A., Tanujaya, E. 2012.Akuntansi Keuangan Menengah Berbasis PSAK.Buku 1. Salemba Empat. Jakarta.

Setiawan. 2008. Analisis Pengaruh Manajemen Piutang dan Persediaan Terhadap Profitabilitas Perusahaan Manufaktur Yang Listing Di Jakarta Islamic Index tahun 2001-2006. Skripsi. UIN Sunan Kalijaga. Yogyakarta. http://digilib.uin-suka.ac.id//1115/ diakses pada 21 mei 2012.

Soemarso,S.R.2009.Akuntansi Suatu Pengantar. Jilid 1. Salemba Empat. Jakarta.

Sugiyono. 2011. Metode Penelitian Kuantitatif Kualitatif dan R\&D. Alfabeta. Bandung.

Sumarsan, T. 2011. Akuntansi Dasar \& Aplikasi dalam Bisnis. Jilid 3. PT. Indeks. Jakarta.

Tjahjono, A., Sulastiningsih. 2009.Akuntansi Pengantar 2 Pendekatan Komprehensip. Cetakan Pertama. Ganbika. Yogyakarta.

Wicaksana. 2010. Analisis Pengaruh Pengendalian Piutang Terhadap Efektivitas Arus Kas (Studi kasus pada PT. Z). Skripsi. Institut Pertanian Bogor. Bogor. http://repository.ipb.ac.id/handle/123456789/47764 diakses pada 8 Juli 2011. 